Cómo citar este artículo / How to cite this article: Mauro, C. M. (2021). Nuestro criterio había de ser mucho más beneficioso para la ciencia: Vives Escudero's contribution to Phoenicio-Punic archaeology in the contemporary cultural context. Lucentum, XL, 345-357. https://doi.org/10.14198/ LVCENTVM.17189

\title{
NUESTRO CRITERIO HABÍA DE SER MUCHO MÁS BENEFICIOSO PARA LA CIENCIA: VIVES ESCUDERO'S CONTRIBUTION TO PHOENICIO-PUNIC ARCHAEOLOGY IN THE CONTEMPORARY CULTURAL CONTEXT
}

\author{
NUESTRO CRITERIO HABÍA DE SER MUCHO MÁS BENEFICIOSO PARA LA CIENCIA: UNA LECTURA \\ DE LA CONTRIBUCIÓN DE VIVES ESCUDERO A LA ARQUEOLOGÍA FENICIO-PÚNICA A LA LUZ \\ DEL CONTEXTO CULTURAL CONTEMPORÁNEO
}

\author{
CHIARA MARIA MAURO \\ Universidad Complutense de Madrid, España \\ cmauro@ucm.es \\ https://orcid.org/0000-0001-8902-0697
}

Recepción: 03/07/2020

Aceptación: 18/03/2021

\begin{abstract}
Antonio Vives Escudero is a key figure in understanding the rising interest in antiquities in early $20^{\text {th }}$-century Spain. However, scholars have more frequently acknowledged his role as a collector or antiquarian rather than his involvement in contemporary intellectual debate. On the one hand, it is true that, at this stage, it is difficult to discern antiquarianism from archaeology; additionally, such a categorisation contributed to underlining some of Vives' strong points (e.g. his commercial instinct). Conversely, this interpretation has undermined his intellectual role, reducing the importance of his contribution to the development of Phoenicio-Punic archaeology in Spain. Therefore, the general aim of this contribution is twofold. It contextualises Vives into the wider scenario of the rising interest in Phoenicio-Punic archaeology and addresses the central question of whether, behind his commercial and collecting interests, he made a real contribution to the development of Phoenicio-Punic archaeology in Spain.
\end{abstract}

Key words. Antonio Vives Escudero; Phoenicio-Punic archaeology; Puig des Molins; Delattre; Juán Román y Calvet; Carlos Román Ferrer; Sociedad Arqueológica Ebusitana.

\section{Resumen}

Antonio Vives Escudero es un personaje clave para entender el desarrollo del interés hacia la arqueología fenicio-púnica que tuvo lugar en España a principios del siglo XX. Su papel como coleccionista y anticuario ha sido frecuentemente reconocido; sin embargo, no se ha hecho suficiente hincapié en su involucramiento dentro del contexto cultural contemporáneo. La categorización de Vives como anticuario, si bien por un lado ha evidenciado algunas de sus características más destacadas (ej. su instinto comercial), por el otro casi ha puesto en duda su aportación intelectual, mermando su rol dentro del proceso de desarrollo de la arqueología fenicio-púnica en España. Este artículo, por lo tanto, tiene un doble objetivo. En primer lugar, pretende contextualizar las obras de Vives dentro del panorama cultural de su época para entender mejor algunas de sus elecciones; en segundo lugar, aspira a destacar su contribución a la arqueología fenicio-púnica española e internacional.

Palabras clave. Antonio Vives Escudero; arqueología fenicio-púnica; Puig des Molins; Delattre; Juán Román y Calvet; Carlos Román Ferrer; Sociedad Arqueológica Ebusitana.

Financiación: Part of this research has been funded through the COST (European Cooperation in Science and Technology) Action 1840 (Grant no. CA18140-46421). 


\section{INTRODUCTION}

At the turn of the $20^{\text {th }}$ century, the rising interest in Phoenicio-Punic antiquities fostered an intense movement of ideas amongst scholars, aimed at developing a framework for studying the previously little-known Phoenicio-Punic culture. This process was certainly eased by two phenomena that took place almost simultaneously: on the one hand, the increase of excavations in regions once interested by the Phoenician presence ${ }^{1}$; on the other, the organisation and celebration of the Universal Exhibitions and other specialised fairs, which provided an ideal physical and cultural setting to nurture the creation of a common scientific knowledge.

In Spain, three areas, in particular, contributed to widen the dataset available on the Phoenicio-Punic culture: Cádiz, Villaricos and Ibiza (Ferrer Albelda, 1996: 86-88). In Cádiz, the first, significant discovery was made in 1887 , when a masculine sarcophagus was unearthed, swiftly attracting the attention of several scholars (i.e. Hübner, 1888: 257-258; Rodríguez de Berlanga, 1902). At Villaricos, the Punic-Roman necropolis excavations began under the direction of Luis Siret (Siret, 1908). Lastly, on the island of Ibiza, the earliest archaeological works started at the beginning of the $20^{\text {th }}$ century under the aegis of the SAE (Sociedad Arqueológica Ebusitana) and they continued until 1910. From that moment, up to 1914, it was Vives who took over the excavations at the necropolis of Puig des Molins.

Active in academic circles for over 30 years (c. 1890s-1925), Antonio Felipe de Jesús Vives y Escudero has been one of the most prominent numismatics of the past century. However, his contribution to scholarship has frequently been criticised, since on some occasions his collector interests seem to have surmounted his scrupulousness as a scholar. In particular, with regard to his contribution to Phoenicio-Punic archaeology, the case of his excavations at Puig des Molins (Ibiza) appears to be emblematic and has received significant scholarly criticisms (e.g. Tarradell \& Tarradell-Font, 1975). The archaeological campaigns that Vives conducted in the necropolis started in 1910, soon after the death of Juan Román y Calvet ${ }^{2}$, and continued until 1914. During this period, Vives had a dispute with Juan Román's son, Carlos Román Ferrer: this legal action eventually led

1. In 1878, Delattre began the excavation at Carthage (Fumadó Ortega, 2009: 88); some years later, Gsell and Duhar published their studies on Algeria. In Italy, between 1904 and 1906, Patroni published details of his work on the Nora site (Sardinia), Taramelli excavated the necropolis of the Cagliari's area (Sardinia), while Withaker started his works at Motya (Sicily). Almost simultaneously, Mayr published an account of his works on the Punic tombs discovered on the island of Malta (Fernández Gómez, 1985: 152).

2. Juan Román y Calvet was, at that time, Director of the SAE and had been leading the archaeological campaign in the necropolis since 1903.
Vives to be the only archaeologist excavating at Puig des Molins, thus interrupting Carlos Román's works in the same area. After the resolution of this lawsuit and the promulgation of the Ley de Excavaciones, Vives concluded his archaeological campaigns on the island of Ibiza and deposited the materials that he found at the Museo Arqueológico de Madrid (hereafter, MAN). From that moment on, it was Carlos Román Ferrer who led the excavations at the necropolis.

Compared to Román Ferrer's methodology, Vives' working procedure appears to be at least less transparent, since he did not keep an account of his work through an excavation diary. Additionally, Vives' choice to transfer all his archaeological findings to Madrid, thus far from their original context, contributed in creating a sort of leyenda negra around him, incentivising his negative reception. Therefore, the general aim of this paper is to address the central question of whether, behind his commercial and collecting interests, Vives made an actual contribution to the development of Phoenicio-Punic archaeology in Spain. To this end, Vives will be placed into the wider intellectual scenario of that period, when a significant movement of ideas was taking place among different scholars interested in Phoenicio-Punic archaeology. To start with, his approach to Phoenicio-Punic archaeology will be examined, identifying the considerations that might have led him to develop a scientific interest in the island of Ibiza; secondly, the criteria he decided to follow during the excavation (if any) will be determined; lastly, his published and unpublished works on Phoenicio-Punic archaeology will be used to understand how he engaged with contemporary Phoenicio-Punic scholarship. The ultimate goal is to offer an adequate analysis of Vives as a scholar, thus avoiding the risk of undervaluing his impact and having a one-sided conceptualisation of his role.

\section{VIVES' APPROACH TO THE ISLAND OF IBIZA}

Addressing the topic of the professional connection between Vives and the island of Ibiza is perhaps best understood by appreciating when and how it occurred in the first place; identifying the period and the modalities in which this approach was conducted can, in fact, shed light on the possible reasons that attracted Vives to the island in general and to Phoenicio-Punic antiquities in particular.

Vives was born in Madrid in 1859 to Minorcan parents (Mederos Martín, 2014: 417). Although he was interested in numismatics from childhood (Castañeda, 1925: 15), he would professionally devote himself to the study only at a later stage (Mederos Martín, 2014: 417). In 1890, he enrolled into the Escuela Superior de Diplomática (Archive of the UCM, hereafter, AGUCM, Exp. ED-28, 19). From that moment on, whilst still a student, Vives began to collaborate with the MAN and 
publish extensively on numismatics (de la Rada, 1892; Vives, 1893). There is little doubt that these professional experiences allowed him to eventually widen his network, thus facilitating the expansion of his collection of antiquities: his first sales to the MAN date from these same years (Archive of the MAN, Exp. 1891/11; 1892/14-B; 1893/2; 1896/16).

His interest in the island of Ibiza can be officially traced back to 1904. At that time, Vives had already graduated $^{3}$, and was a member of the Real Academia de la Historia (Mederos Martín, 2014: 421-422). In the same year, the Real Academia granted him with the task of writing the Catálogo Monumental de las Islas Baleares. It was the same Vives - on the 7th of Julywho asked to be entrusted with this part of the Catálogo Monumental de España (hereafter, CME), supporting his request with the statement that he had frequently visited the Balearic Islands and that he had gathered all the requirements needed for this task. In fact, since 1903, he had already been conducting excavations on the island of Menorca. The task of compiling the catalogue was officially entrusted to him in 1905, through the Real Orden was dated to the $20^{\text {th }}$ of January, 1905 (Mederos Martín, 2014: 423). However, this work was never published, although it was delivered - under the Deputy Minister's explicit request- in $1909^{4}$.

Vives' choice to work on the Balearic Islands could be construed in light of two parallel processes: one taking place in Spain, the other at international level. As underlined in the Introduction, significant new discoveries were made from the end of the $19^{\text {th }}$ century, drawing international attention to Phoenicio-Punic archaeology. As far as the international scenario is concerned, Renan (1864) published a pioneering book on his archaeological expedition to Levant, introducing the results of his excavations of various Phoenician settlements to the scholarship. Barely a decade later, Alfred Louis Delattre (a member of the White Fathers) began his excavation on the site of Carthage, exposing the remains of the city. With regard to Spain, the situation was no less vibrant. Almost contemporarily, Cádiz was the protagonist of another relevant finding related to the Phoenicio-Punic culture: at Punta de Vaca, an anthropoid sarcophagus was rescued, attracting the attention of various scholars (Almagro-Gorbea et al., 2010; Mauro \& Salas, 2020) .

In 1892 , the successful excavation conducted by Delattre and the White Fathers at Carthage eventually reached the attention of the Spanish intellectual community. In that year, Madrid hosted the Exposición Histórico-Europea, to which French Tunisia contributed

3. He received the title of 'Archivist, Librarian and Archaeologist' in 1901 (AGUCM, Exp. ED-28, 19).

4. Theoretically, Vives had to complete the work within a year, since it was established he would be paid 600 pesetas monthly for twelve months.

5. For earlier discoveries, see Mederos Martín, 2001.

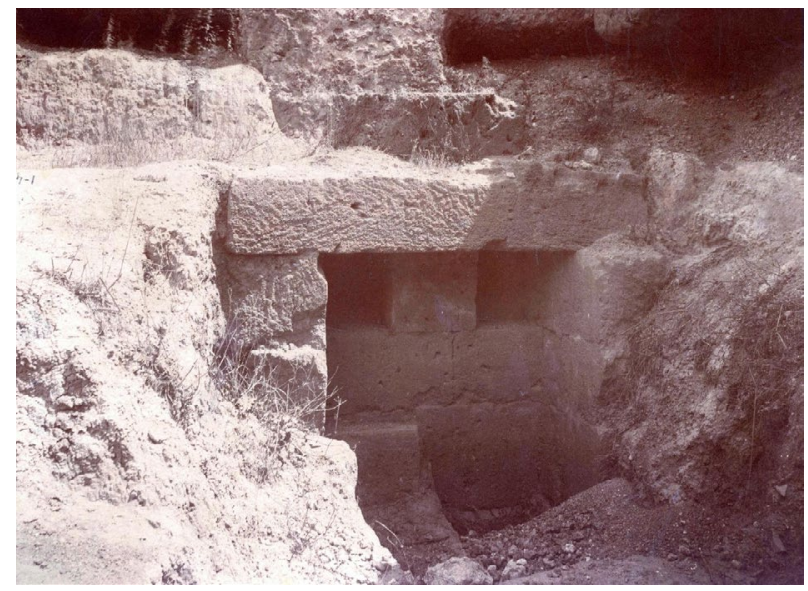

Figura 1: One of the photographs sent by Father Delattre to the Exposición Histórico-Europea, depicting the rear part of a Punic funerary chamber, exposed in the Room no. 3 (Tunisia), amongst the photographs of the 'primer cuadro'. Size: 17 x 22.5 cm. Catalogue, no. 4; MAN, no. 1892/29/FF-146

by sending eleven boxes containing photos of Delattre's discoveries at Carthage (Fig. 1) ${ }^{6}$. The dissemination of Delattre's results (carried out through exhibitions presenting the photographs of his discoveries, but also through a considerable number of publications) had an almost immediate impact on the international scenario in general and on the Spanish in particular, as the continuation of the excavations in Cádiz (under Rodríguez de Berlanga until 1912, and then under Quintero Atauri) and the opening of new ones in Andalusia (e.g. in Villaricos by Siret and in Carmona by Bonsor) and Ibiza seem to confirm (Ferrer Albelda, 1996: 86-88).

It is in this same context that Vives' interest in the island of Ibiza was probably awakened. In 1892 , Vives was, in fact, collaborating with the MAN, where -as arranged by Juan Catalina García López- he was curating the Arabic antiquities for the Exposición Histórico-Europea (Mederos Martín, 2014: 420). Although there is no direct evidence that he saw Delattre's photographs, it is therefore highly probable. Furthermore, we know that Delattre's photographs were appreciated to the point where a Board ${ }^{7}$ awarded him a medal (Archives of the Society of Missionaries of Africa, hereafter, MAfr. Y1.IV) (Fig. 2) and that, after the exhibition, 389 photographs were donated by the Bey of Tunis -Ali Bey- to the MAN (Mélida Alinari \& Álvarez Ossorio, 1896: 178) $)^{8}$.

In view of the rising interest in Phoenicio-Punic archaeology at the beginning of the $20^{\text {th }}$ century, other important events related to Ibiza occurring before 1904

6. MAN, Exp. 1892/29-AS.

7. On the composition of these Boards, Rodrigo del Blanco, 2018: 53.

8. The photos donated are those from $1892 / 29 / \mathrm{FF}-1$ to $1892 / 29 /$ FF390. They can be viewed at: http://www.man.es/man/coleccion/catalogos-tematicos/tunez.html 


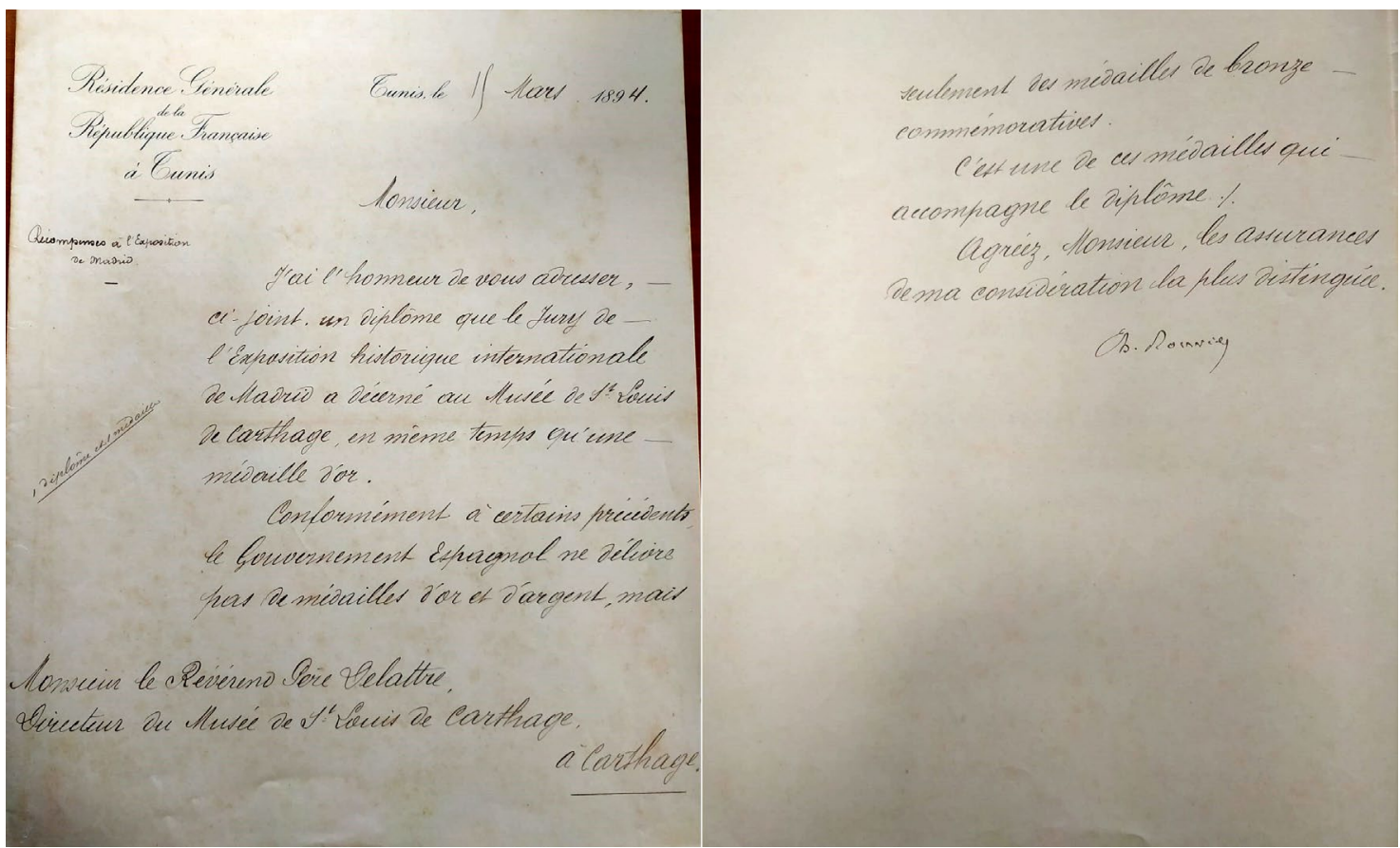

Figura 2: Official letter sent to Father Delattre announcing that the Board of the Exposición Histórico-Europea had awarded him a bronze medal. MAfr. Y1.IV

could have contributed to attracting Vives' attention to the island. These events are partially connected with the new discoveries made in the field of numismatics, which comprised Vives' primary research interest; therefore, they could reinforce the idea that Vives may have been attracted by the new possibilities presented by the island, or -at least- could have been aware of them. In 1891, Alvaro Campaner had argued that ancient coins found on Ibiza and previously attributed to foreigner mints had, in fact, to be allocated to an island mint, thus recognising that Ibiza could have hosted a major settlement during the Phoenicio-Punic period $^{9}$. Some years later, a news item appeared on the Diario de Ibiza disclosing the discovery of significant numbers of antiquities at a place known as Puig des Molins (Fernández Gómez, 2018: 313). In 1903, a site confirmed to be a necropolis began to be systematically excavated by the Sociedad Arqueológica Ebusitana (SAE), a small society composed of a group of local amateurs $^{10}$.

In light of the above-mentioned events, reading Vives' request to take charge of the Catálogo Monumental de las Islas Baleares acquires new meanings.

9. Campaner's work is known by Vives, evidenced by its reference in the Catálogo Monumental de las Islas Baleares (Vives, 1909: 174) proves.

10. Vives' awareness of the situation on Ibiza seems to be confirmed by the fact that he is mentioned amongst the contributors who donated books to the Library of the SAE in 1904 (Fernández Gómez, 2018: 317; Pérez-Cabrero, 1911: 9).

\section{THE CATÁLOGO MONUMENTAL DE LAS IS- LAS BALEARES}

Vives was certainly in Ibiza in 1907, at Juan Román y Calvet's invitation (Fernández Gómez, 2018: 323$329)^{11}$. On that occasion, he also took part in the archaeological expedition that resulted into the discovery of the Es Culleram sanctuary (Román Ferrer, 1913: 69-87).

The possibility of direct access to the cultural heritage of the island has clear repercussions for the Catálogo Monumental de las Islas Baleares that was eventually delivered in 1909. In particular, a careful screening of this work can unveil interesting clues concerning Vives' intellectual framework and his method of conceiving archaeological studies. Firstly, the catalogue consists of four volumes, three of which are composed entirely of illustrations, whereas the remaining volume contains the descriptive section (Vives, 1909). The attention that Vives devoted to the graphic material is perfectly in line with the reformer principles of the archaeological discipline at the beginning of the $20^{\text {th }}$ century (Bermejo Tirado \& Mañas Romero, 2012: 217): beyond providing his catalogue with sketches, plans and sections, he attached a significant number

11. In 1907, Román y Calvet was appointed as a correspondent of the Real Academia de la Historia. He exposed some of the objects he found on the island of Ibiza in the MAN (as it results from the Actas de la $R A H$, dated to the $28^{\text {th }}$ of June 1907) and presented photographs of his findings to the members of the RAH (Actas de la RAH, dated the $25^{\text {th }}$ of October 1907). 
of photographs, employing innovative techniques (Algerich Fernández, 2012: 117). At that time, the documentary value of photography in archaeology was not yet widely assumed; in this sense, Vives' early use of such an approach should be read as an attempt to adjust his scholarly production to international standards ${ }^{12}$.

The structure and its attachments are not the only examples whereby Vives' work greatly differed from the other parts of the Catálogo Monumental de España (hereafter, CME): in fact, in the descriptive part (Vives, 1909: vol. I), the cultural historicism that the author adopted appears to be a fairly-widespread theoretical paradigm in early $20^{\text {th }}$ century Europe (Díaz-Andreu et al., 2009: 36). Despite being arranged as a catalogue, as was required by the overall design of the $C M E$, Vives brought about pertinent changes: his classification work was more systematic, with all the materials being divided according to their corresponding typology; there is little doubt that his background as a numismatist, together with the positivist influence of the second half of the $19^{\text {th }}$ century, deeply shaped the way in which he conceived this publication.

With regard to Ibiza's Phoenicio-Punic phase, Vives decided to divide the materials into seven groups; namely, terracotta and pottery, ivory, glass, ostrich's eggs, engraved gems, metals, and coins (Fig. 3). The objects he included were either already published in Román y Calvet's monography (Román y Calvet, 1906) or intentionally omitted (Vives, 1909: 180); each one is carefully described, accompanied by a sketch or a photograph, and -in most of the cases- compared to similar findings ${ }^{13}$. As already mentioned, the existence of detailed graphic documents was particularly valuable at that time: in these first phases of Phoenicio-Punic archaeology, illustrations made the materials accessible to other scholars, thus easing the identification of possible comparisons. Additionally, for each object, the current location and the place of the discovery were specified. In the case of its current location, data is quite detailed, and it is noted that some of the items are said to be part of the Colección Vives, thus meaning that Vives had already started to assemble his island collection before 1909 (Fig. 4). On the other hand, the place

12. In Spain, Vives was one of the pioneers regarding the use of photography, beginning as early as 1889 (as documented in Paris, 1889: 113). He probably became more aware of the potentialities of this tool during the spring of 1898 , when he took part in a scientific cruise organised by the Revue Générale des Sciences, where diapositives were used to illustrate different lectures and talks (González Reyero, 2007: 215).

13. Vives appears to be already familiar with the terracotta preserved in the Louvre Museum (Heuzey, 1883) and other findings from Sardinia (Crespi, 1868; Patroni and Taramellis's works were possibly too recent for Vives to know) and Carthage (Delattre, 1897; 1899-1900; 1900). Lastly, it is interesting to underline that in Delattre (1900), a typological classification was conducted, similar to that adopted by Vives.

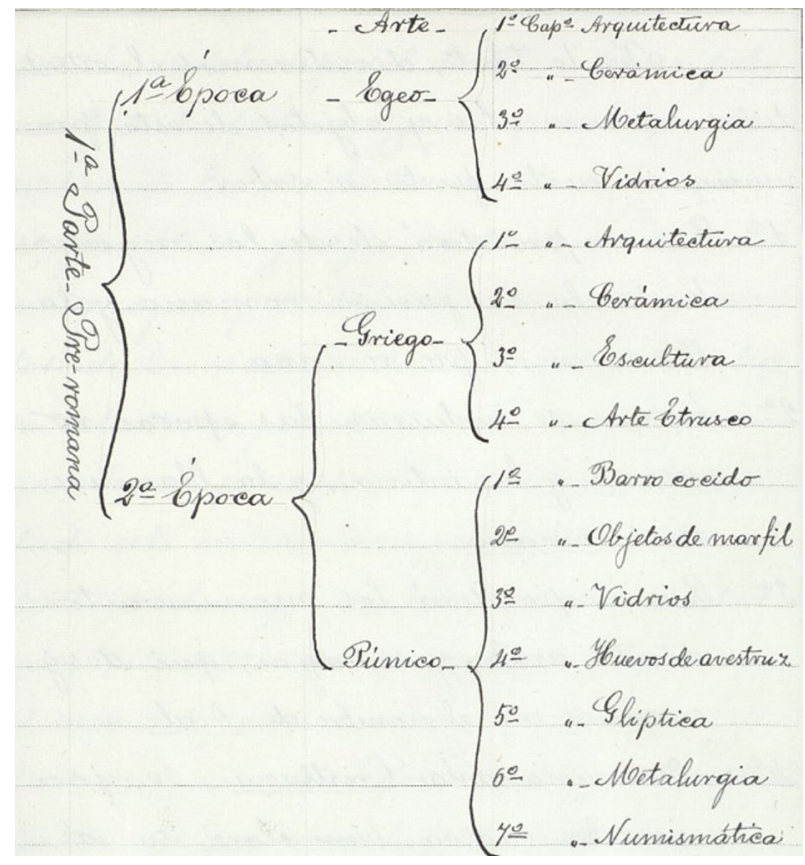

Figura 3: Divisions in typologies adopted by Vives for his Catálogo Monumental de las Islas Baleares (Vives, 1909: 4)

of the discovery is almost always excessively general, e.g. 'necropolis de Ibiza' or 'San Rafael'. This lack of detail can be justified in light of Vives' statement that denounces Román y Calvet as having conducted nonsystematic explorations in different areas of the island (Vives, 1909: 181) $)^{14}$.

The comparison between Vives and Román y Calvet is pinpointed, arguing that Román neither specialised in historical and archaeological studies (Vives, 1909: $178)^{15}$ nor recorded his findings in an excavation diary (Vives, 1909: 181-182) ${ }^{16}$. Later, Vives added that Román dated some of his findings without having previously systematically classified all the materials. This claim clarifies Vives' conception of the cataloguing as an essential part of the scientific work ('Nuestro deseo, en un principio, fue ceñirnos lo más posible al criterio del Sr. Román, pero luego comprendimos que había de ser mucho más beneficioso para la ciencia'; Vives, 1909: 182).

14. However, as can be seen later, the exact place of provenance would not be detailed in Vives' next work, either, when he led the archaeological excavations.

15. Vives recognised, however, that he had outstanding knowledge (1909: 178).

16. 'Conviene advertir, que por efecto del proceso indicado, es decir de haberse hecho las excavaciones, primero por la «Sociedad arqueológica», luego por el Señor Román, no solo como socio sino particularmente, y esto último no sistemáticamente sino a manera de exploración en diferentes puntos de la Isla, no se ha llevado como fuera de desear un libro ó diario de excavaciones en que se puntualizaran todos los detalles y circunstancias de los trabajos.' 


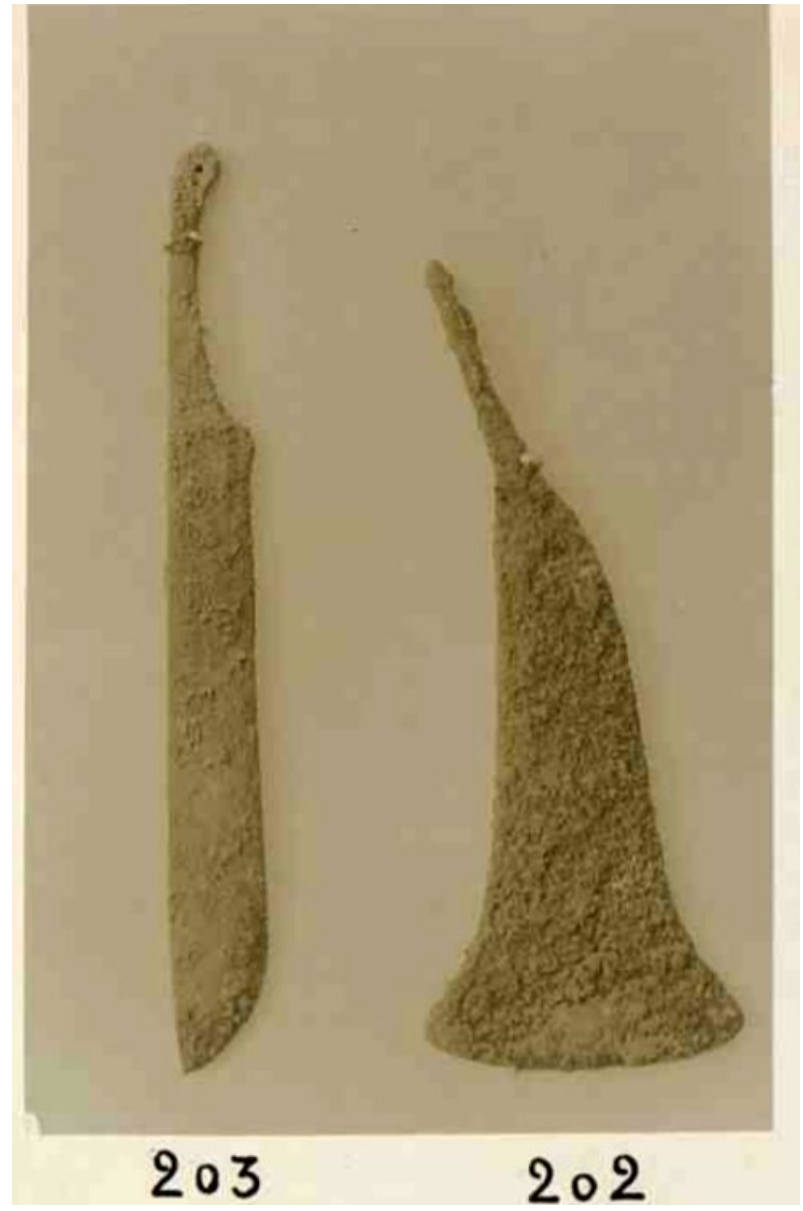

Figura 4: Bronze knife (no. 203) and razor (no. 202) belonging to the Vives' collection: the exact location of their discovery is not detailed. In Vives (1909: 250), they are compared to Delattre's findings in Carthage, despite the Tunisian samples frequently being engraved with decorations

\section{VIVES' EXCAVATIONS AT PUIG DES MO- LINS AND THE STUDY OF THE FINDINGS}

Juan Román's death, on the $10^{\text {th }}$ of January 1910 , interrupted both his excavations at Puig des Molins and the preparation of a new monograph on Ebusitan archaeology ${ }^{17}$. With regard to the former, an article appeared in the Anuari de l'Institut d'Estudis Catalans (1909: 555557), stating that the sketches were already finished (Fernández Gómez, 2018: 329). Additionally, archival documents and the contemporaneous press reveal that Román y Calvet had previously entered in contact with different scholars -both through epistolary exchange (including with the afore-mentioned Father Delattre)

17. The first monograph, titled Los nombres e importancia arqueológica de las islas Pithyusas, was published in 1906, being the first actual work on the archaeology of Ibiza and Formentera.
(Fig. 5) or participation in international conferences ${ }^{18}$ to gather the necessary information and bibliography.

Soon after Román y Calvet's death, Vives began his own excavation at Puig de Molins ${ }^{19}$. To this end, he rented the properties known as es Porxet and can Xico Roig, which were previously occupied by Juan Román, also making use of the same specialised manpower (Fernández Gómez, 2016: 21). There, he conducted archaeological campaigns until 1914, when a Real Orden (23 $3^{\text {rd }}$ of May) was established to stop all the excavations at Puig des Molins (Fernández Gómez, 2018: 339$)^{20}$. Since the events connected to the legal vicissitudes between Vives and Carlos Román Ferrer ${ }^{21}$ and between the former and the Spanish State have been exhaustively addressed by Fernández Gómez (2011; 2016; 2020) and Mederos Martín (2014), the focus will be exclusively on the -scarce- extant information on Vives' methodology, and on the scientific discussion that he created through the studies that he conducted on his findings.

The absence of an excavations diary is probably the first notable exception regarding Vives' archaeological campaigns, especially since he denounced this same lack when referring to Román y Calvet's work (Vives, 1909: 181). According to Fernández Gómez (2016: 21-22), the justification for this deficit can be found in Vives' description of the status of the necropolis (i.e. Vives, 1917: XXIII-XXIV) ${ }^{22}$; in other words, in Vives' opinion, the situation was already compromised to a point where it was impossible to reconstruct the original setting ${ }^{23}$. Moreover, Mederos Martín (2014: 427) suggests that the same Vives could not have been regularly present on the set of the excavations, having become Professor of Numismatics and Epigraphy at the Universidad Central de Madrid in 1912. In any case, the correlation between the objects Vives found at Puig des Molins (today preserved at

18. The Diario de Ibiza gave advance notice of Román y Calvet's participation at the International Congress of Historical Sciences held in Berlin in 1908 (Diario de Ibiza, 23/07/1908) and at the 2nd International Conference of Classical Archaeology held in El Cairo in 1909 (Diario de Ibiza, 06/04/1909) (Fernández Gómez, 2019: 320).

19. Before that, he sought to excavate in other areas; however, there is no further detail on this phase (Fernández Gómez, 2018: 337).

20. During this period, Antonio Vives Escudero published a contribution on the ancient coins of Gades, in which he also catalogued the pre-Roman mintages, i.e. Vives, 1913.

21. Son of Juan Román y Calvet.

22. '... eso dará una idea de lo removido que está el contenido de tales enterramientos, pudiéndose asegurar que, excepto por una casualidad, o tratándose de objetos muy pequeños, escarabeos o cuentas de collar, nada de lo que hoy se encuentra en una cámara debió depositarse en ella, sino que ha llegado allá mediante el trasiego de los sucesivos registros'.

23. As Román Ferrer's works proved, the context was not damaged to the point of preventing accurate excavations (Román Ferrer, 1922; 1923; 1924; 1926; 1927). 


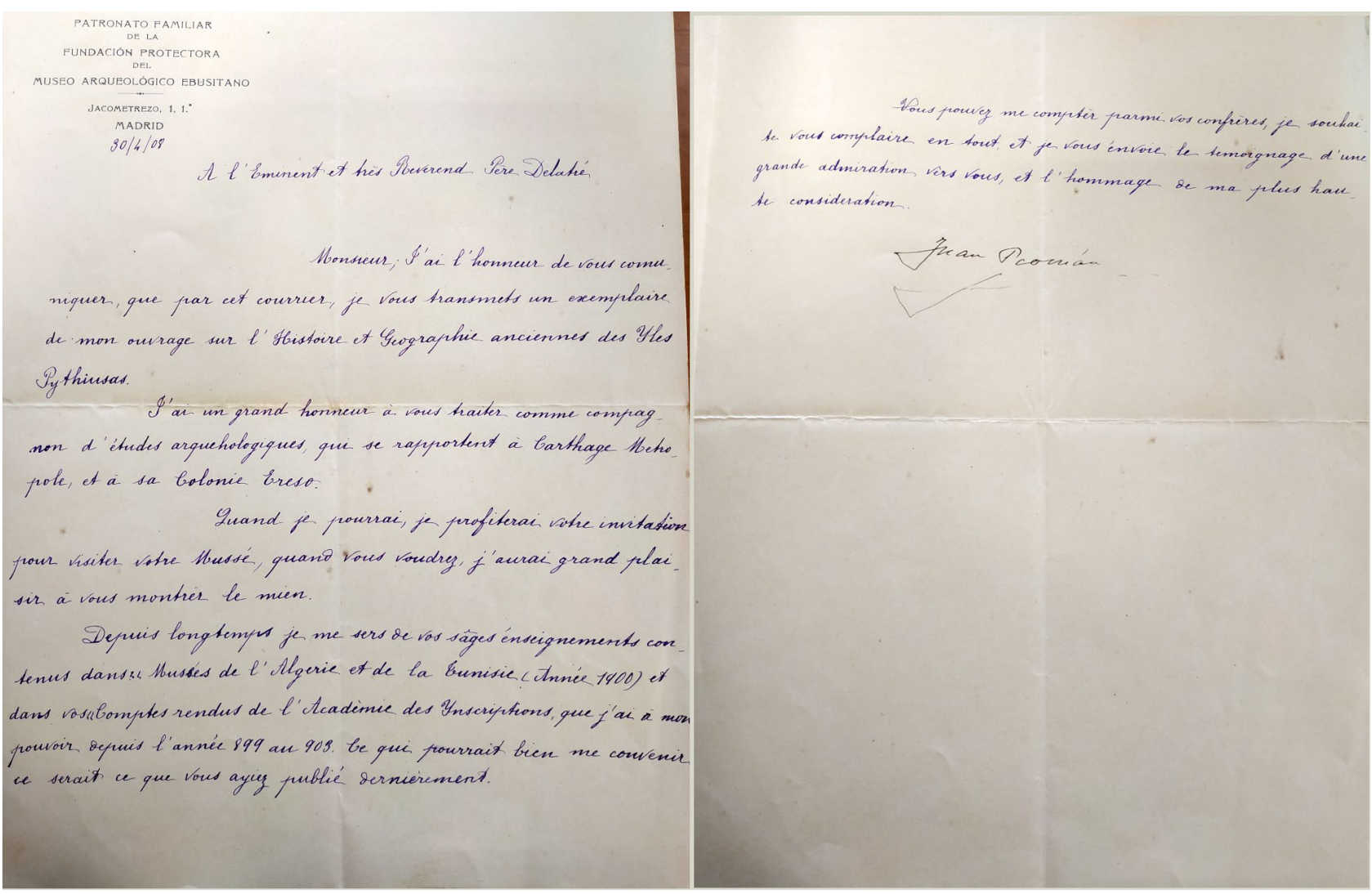

Figura 5: One of the letters sent by Juan Román y Calvet to Father Delattre. MAfr. Y5

the MAN) and the different hypogea has been lost, and the only details concerning this excavation emanate from Vives' monograph (Vives, 1917: XXIV-XXV) and from a document that the lawyer Julio Ferrer $y$ Baonza delivered, in Vive's name, to the Ministerio de Instrucción Publica y Bellas Artes in 1914 (Fernández Gómez, 2011: doc. 4). In particular, the former document states that, between 1910 and 1914, Vives' campaigns concerned approximately 400 hypogea, from which 2003 items were recovered. However, neither of the above-mentioned documents provide information on the composition of the grave goods of the single burials ${ }^{24}$.

24. To this end, it would be interesting to compare Vives' working procedure with that of George Bonsor, who excavated the necropolis 'La Cruz del Negro' (Carmona, Sevilla) between 1900 and 1905, or Luis Siret. Although the necropolis of Carmona was also already illegally excavated, Bonsor was, in any case, able to produce a thorough documentation of his work. Furthermore, he drew numerous sketches and plans where he indicated the exact location in which he found the objects inside the burials, thus easing the study of the funerary ritual employed in the necropolis (Maier, 2012). As for Luis Siret, notes, field diaries and sketches related to his excavations at the necropolis of Villaricos are also preserved (all these documents have been digitalized by the MAN under the name 'Archivo Siret').
In 1916, the items found at Puig de Molins, together with some materials having a different provenance, were deposited at the $\mathrm{MAN}^{25}$. The exact reason behind this choice it is difficult to discern, even if it possible that Vives was waiting for his controversy with the State to be finally solved (Mauro \& Salas, 2020). However, if -on the one hand- the decision to transfer this collection to Madrid attracted significant criticism ${ }^{26}$, on the other, it allowed its retention within the Spanish borders $^{27}$, affording Vives the possibility of keeping it in sight while preparing his monograph on Ebusitan archaeology, eventually published in 1917.

The monograph was devoted entirely to the study of the Puig des Molins findings and structured in a similar way to the 1909 Catalogue. For his preparation,

25. The deposit, composed of 2171 objects, was formalised only in 1923 (MAN, Exp. 1923/60); it would be purchased by the MAN over four different lots between 1927 and 1929, following Vives' death (see Mauro \& Salas, 2020, for further details).

26. This includes both contemporaneously (Diario de Ibiza, 24/08/1909; see also Cazurro in AGA Junta Superior de Excavaciones y Antigüedades 1914 no. 10, cited by Fernández Gómez, 2016: 210) and a posteriori (Tarradell \& Tarradell-Font, 1975: 20-21).

27. After the excavations at Puig des Molins were interrupted in 1914, many findings left the country illegally (Tarradell \& Tarradell-Font, 1975: 23). See also Casado Rigalt, 2006: 144. 
Vives travelled to different European museums and various other sites searching for possible comparisons (Tarradell \& Tarradell-Font, 1975: 24-25). With regard to the knowledge of collections in foreign museums, Vives evidently knew -directly or indirectly- those of the British Museum, the museums of Berlin, Cagliari, New York, Palermo, Siracusa and Malta, and the Louvre Museum (Vives, 1917). As for research travels, in 1918 Mélida (1918: 401-403) published a report on the Boletín de la Real Academia de la Historia in which he stated that Vives was in Sardinia and Algeria with the purpose of cataloguing his findings at Puig des Molins and publishing them, but he did not proffer further detail ${ }^{28}$. Some years later, writing Vives' obituary, the same Mélida (1925: 237-239) reported Vives' research travels to Sicily and Algeria and aimed at the publication of his monograph on Puig des Molins. However, in the absence of specifications, it is not possible to reconstruct Vives' exact movements during these travels, nor to know who he possibly met. Having access to Vives' private documents pertaining to his descendants, Hernández and Marot (2016: 10) reported a journey to Carthage. This could justify Vives' acknowledgement to Delattre (Vives, 1917: XLVIII) ${ }^{29}$, otherwise unsupported by direct correspondence ${ }^{30}$.

As for the bibliography of his 1917 monograph, it appears to be much more comprehensive if compared to that used in 1909, since it also includes archaeological studies made at the beginning of the $20^{\text {th }}$ century. With regard to Sardinia, for example, Crespi's catalogue (Crespi, 1868) is no longer the only source to be employed. In 1917, Vives was already aware of the works made by Taramelli: however, he decided to use only Taramelli's studies on the Collection Gouin (Taramelli, 1914), recently acquired by the Museo di Cagliari, and not to refer to his archaeological excavations in necropolis areas, since Taramelli and Nisardi 'efectuaron algunas excavaciones con sujeción a espíritu científico; pero desgraciadamente las grandes necropolis ya están destruídas, y solo de cuando en cuando se encuentra algún pequeño grupo de tumbas o hipogeos, de contenido escaso e incomparable a los destruídos' (Vives, 1917: XVIII).

With regard to the graphic material, Estudio de Arqueologia Cartaginesa is similar to the previous publication -the Catálogo Monumental de las Islas

28. For example, he did not specify in what year he made these travels, nor he did provide an account of the sites or museums visited by Vives. Vives seems to confirm this travel to Sardinia stating what follows: 'No recordamos haber visto en Cerdeña piezas similares' (Vives, 1917: XXIII).

29. 'No terminaremos sin agradecer a los señores conservadores de los museos de Londres y de Berlín y al Revdo. P. Delattre, del de San Luis de Cartago, por la amabilidad con que nos ha facilitado datos, improntas y fotografías, sintiendo no poder decir lo mismo de otros centros'.

30. Delattre's epistolary does not preserve trace of any letter received from Antonio Vives.
Baleares- comprising numerous sketches, plans and photographs. In fact, some of the materials employed within the monograph have been directly borrowed from the previous, unpublished work; i.e. the Figure 1 (Vives, 1917: lám. XXI) corresponds with Figure 159 of the Catálogo Monumental de las Islas Baleares (Vives, 1909: fig. 159, vol. 2).

\section{THE COLECCIÓN DE ANTIGÜEDADES CART- AGINESAS DEPOSITADAS EN EL MAN AND THE RECEPTION OF VIVES' WORK}

The Vives Collection objects were deposited at the MAN in 1916. As underlined above, there may be several reasons for this choice, amongst which could be the time spent waiting for the resolution to the difficulties he experienced with the Spanish State (Fernández Gómez, 2020) $)^{31}$ and the attendant repercussions that the Ley de Excavaciones could have had on the fate of private Spanish collections.

Despite being publicly visible since $1916^{32}$, the deposit was formalised only seven years later, in 1923 (MAN, Exp. 1923/60). In the meantime, Vives was assigned an additional position, having become Head of the Instituto Valencia de Don Juan on February $1922^{33}$ (Fig. 6). On the occasion of the formalisation of the deposit at the MAN, Vives delivered a catalogue to the museum, titled Colección de Antigüedades Cartaginesas depositadas en el Museo Arqueológico Nacional por D. Antonio Vives y Escudero, also dated to 1923. The catalogue is handwritten inside a lined notebook with a hard cover and it contained 135 pages. The spine is divided by six raised bands, two of which bear the captions 'Inventario Antigüedades Cartaginesas' and the date; i.e. 1923 (Vives, 1923). This manuscript includes a detailed list of all the objects pertaining to the collection, wherein each item is accompanied by an identification number and a brief description. Additionally, for every cabinet and showcase, one or more photographs are provided (Fig. 7). The photographs of the position of the objects within the cabinets and the showcases (Vives, 1923: fol. 128bis and 129), as well as the two figures showing the location of these cabinets and showcases within Room XVIII, furnish an accurate image of how the collection was formally displayed.

Although the catalogue does not offer new insight to the understanding of Phoenicio-Punic culture, what it surely denotes is twofold: on the one hand, the extreme attention that Vives devoted to the cataloguing and

31. Solved only in 1921.

32. In the plan within the Guide of the Museum, published in 1917, Room XVIII is identified as hosting the 'Antigüedades de la isla de Ibiza (Depósito)' (Guía Histórica y Descriptiva del Museo Arqueológico Nacional, 1917: 51).

33. Vives fulfilled this role from February 1922 until his death in 1925. 


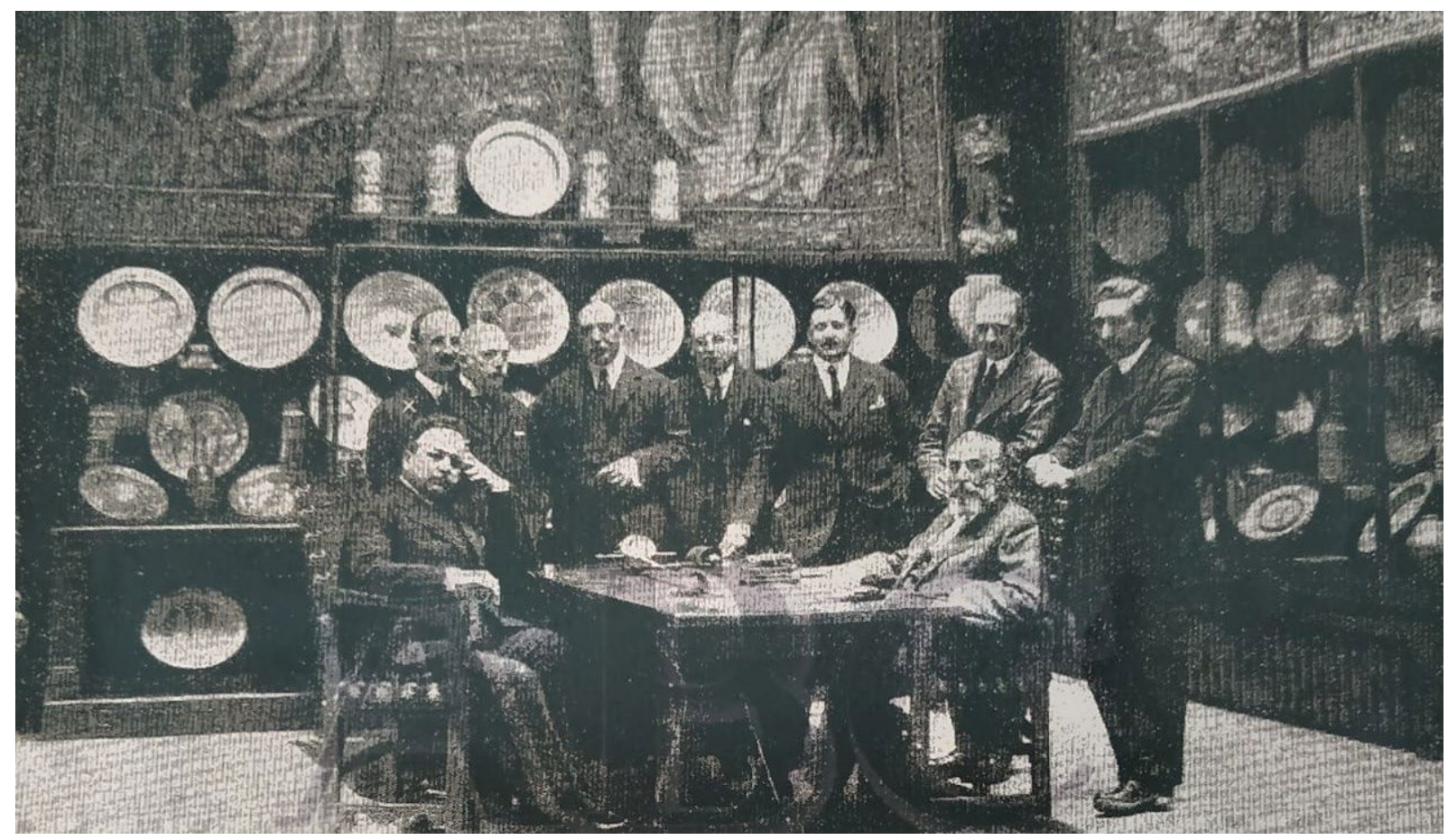

Figura 6: Photo published in the $A B C$ newspaper, Madrid, the $18^{\text {th }}$ of April 1922, and representing a visit made by the Sevillian architect Anibal González y Alvarez Ossorio (standing on the left) with an accompanying entourage at the Instituto Valencia de Don Juan. Vives, at that time Head of Institute, is seated on the right

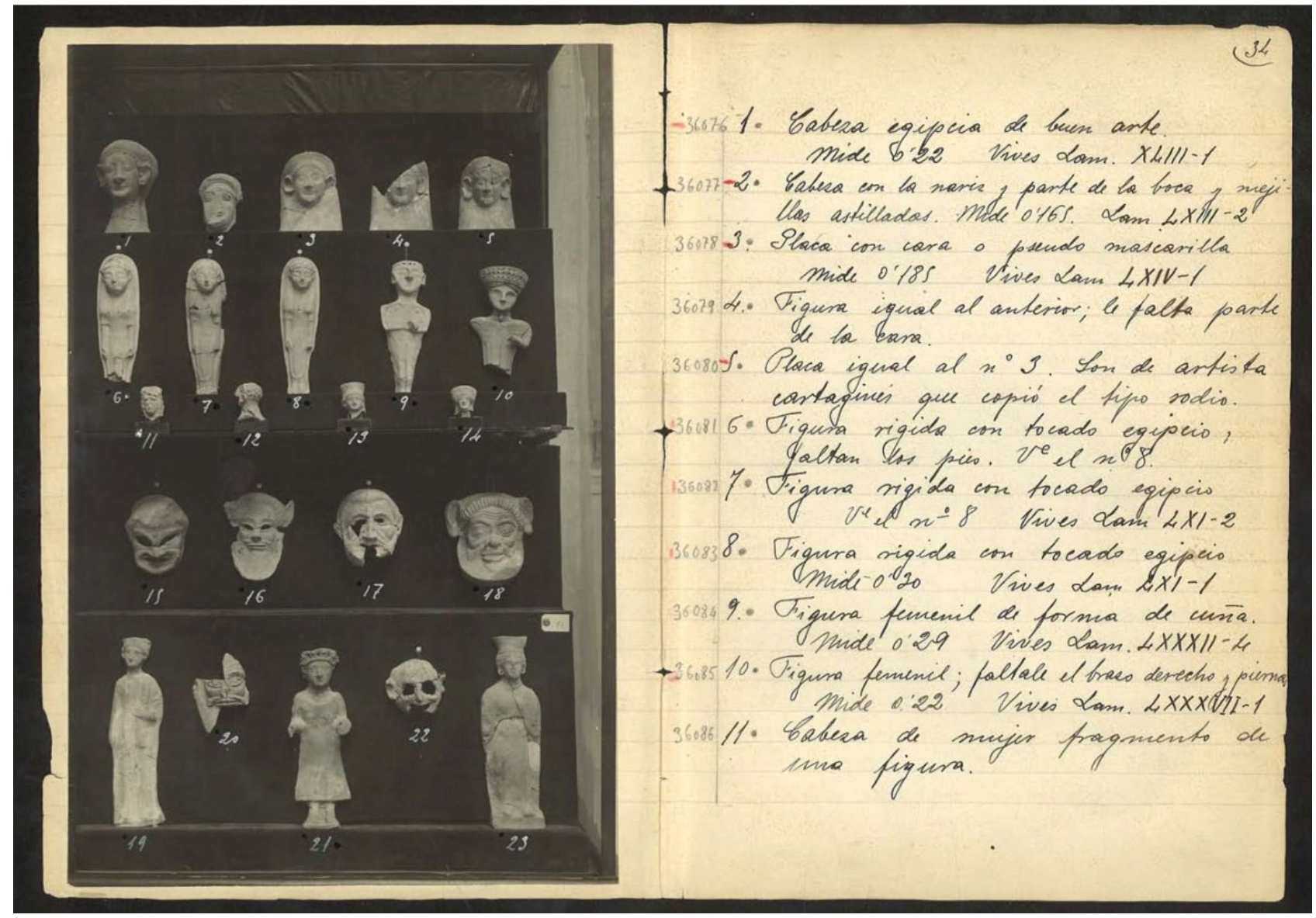

Figura 7: The catalogue delivered to the MAN by Antonio Vives Escudero in 1923: photograph of the cabinet no. 7 (right part) (Vives, 1923: fol. 34) 
systematisation of his findings; on the other, it underscores once again the importance of photography in his scholarly production.

Lastly, even within this manuscript, items are divided according to the same typologies used by Vives to publish the Catálogo Monumental and the Estudio de Arqueología Cartaginesa: however, their collocation order within the cabinets and the showcases differs slightly.

Two years after the formalisation of the deposit, Vives passed away on the 19th of May 1925. Following his death, his wife -Concha Segura- began to sell his collections. The Ebusitan antiquities were thus offered at the MAN, where they were already exhibited. In return, Concha Segura asked for payment of 125000 pesetas. Since the amount was consistent, the MAN agreed to purchase the entire collection but divided it into four different lots, acquired between 1927 and 1929 ${ }^{34}$. In 1929, therefore, the MAN became the official owner of the most important Phoenicio-Punic repertoire in Spain.

From that moment on, the attention that Vives Collection had already gathered since 1916 (i.e. from the moment of its public exhibition) continued to grow. As a result, the Estudio de Arqueología Cartaginesa, Vives' unique published work on the Ebusitan archaeology, was widely consulted. To offer a brief insight to its diffusion, it is worth noticing that in 1929, Vives' studies were used by Mélida as a base to compile a handbook titled Arqueología Española, the first comprehensive study on the ancient material culture found in Spain ${ }^{35}$. Additionally, Vives' work flowed into new summaries on the Phoenician presence in the Western Mediterranean (e.g. Dixon, 1940; García y Bellido, 1942; Bosch Gimpera, 1952 ${ }^{36}$ ) and the photographs and classification he published were frequently used as terms of comparison for cataloguing the new, emerging discoveries (e.g. Lafuente, 1929: 621; Martínez y Martínez, 1943: 23; Ponsich, 1968: 23).

\section{CONCLUSIONS}

To describe Vives as a scholar, Mélida -one of his dearest friends ${ }^{37}$ - states that he was not a man of whom one would expect impressive speeches or discourses; rather, he had a reliable understanding at first glance ${ }^{38}$.

34. MAN, Exp. 1927/11; Exp. 1928/24; Exp. 1928/38; and Exp. $1929 / 14$

35. For the section on the Phoenicio-Punic antiquities on the island of Ibiza, Mélida also consulted Román y Calvet, 1906.

36. Bosch Gimpera used Vives' monograph to organise his classes on Puig des Molins within the 'Cultura Ibérica' course, held at the Universidad de Barcelona (Gracia Alonso, 2020: 249).

37. This is how Mélida describes his relation with Vives in Mélida, 1898: 243-244.

38. Free translation from Mélida, 1925: 238.
This statement acquires clarity after the examination of his production on Phoenicio-Punic archaeology: all his contributions are, in fact, accurate records in which the description, the depiction and the comparison of the objects play a fundamental role. The scheme that Vives followed was almost always the same, with the cataloguing and systematisation of the findings being prioritised. Such meticulous work can be read in two different, yet still compatible, ways: on the one hand, it could have been influenced and strengthened by Vives' background in numismatics; on the other, it could be compared within a general trend occurring in the contemporary Spanish scenario, finding its roots in the second half of $19^{\text {th }}$-century positivism.

Between the $19^{\text {th }}$ and the $20^{\text {th }}$ century, Spain was experiencing a period of transition to which the roots of modern archaeological sciences can be traced. Whilst, until the end of the $19^{\text {th }}$ century, the aim of most scholars was collecting objects for their ancient, artistic or historical value, at the beginning of the $20^{\text {th }}$ it can be noticed how this antiquarianism evolves into something different that can also be observed in Vives' work on Phoenicio-Punic antiquities. In particular, the craving to possess was now converted into a desire for knowing and understanding; a goal that could be achieved -according to the contemporary debateonly through compiling and systematising the entire evidence known to that point. Vives appeared to be perfectly in line with this trend: his struggle to understand the origin, typology and relation of each item is clearly reflected in the way he entangled discussion with other scholars. A serious and constantly-updated engagement with the contemporary state-of-the-art knowledge of Phoenicio-Punic archaeology emerged from his works, occurring through different channels of transmission: travels, readings, and epistolary relationship.

Vives's Phoenicio-Punic publications, if deeply grounded in the positivist spirit, have another visionary characteristic in common; that is, the widespread use of graphic material and specifically, photography. In fact, Vives was one of the first scholars in Spain to rely on this tool, and there is little doubt that the rich illustrations with which he furnished all his works on Phoenicio-Punic archaeology contributed in a significant way to the knowledge of the Puig des Molins necropolis worldwide. Furthermore, Vives' graphic materials offered other scholars a relevant resource at their disposal ${ }^{39}$, giving them access to the funerary rituals of a culture that was, hitherto, poorly known. In a review in the 1918 Numismatic Chronicle, for example, Vives' work is praised for being a 'well-illustrated and elaborate scientific account' and using the collotype 'with very fair success'. Furthermore, 'Señor Vives' is acknowledged because 'he has taken the opportunity,

39. This was the case of the monograph, since the Catalogue and the Colección were not published. 
for which we must all be grateful, of putting together on plates CII-CIV a number of the more important Carthaginian coins, collected from various Museums' (Numismatic Chronicle, 1918: 129-130).

There is no doubt that Vives' lack of interest in the archaeological context caused considerable and permanent loss to the study of Phoenicio-Punic in Spain, and it is possible that different contingencies could have contributed to widening the audience for his scholarly work: Vives was an esteemed professional ${ }^{40}$, and was capable -during his lifetime- of establishing a consolidated network by fulfilling various prominent roles $^{41}$. However, it is equally undeniable that, by being widely cited, revisited (see, for example, the revision to Vives' classification of funerary masks proposed by Cintas, 1946: 38 and 56) and criticised, Vives' work -with its qualities and its demerits- contributed to paving the way for the development of PhoenicioPunic archaeology.

\section{ACKNOWLEDGMENTS}

I would like to thank Dr. Lorenza Ilia Manfredi (Istituto di Scienze del Patrimonio Culturale, CNR, Rome, Italy) for hosting me during the archival research carried out at the Archives of the Society of Missionaries of Africa (White Fathers) in Rome (under the CostAction 18140 scheme). Furthermore, I would like to express my gratitude to Aurora Ladero Galán, Ana Rocasolano Díez, Asunción Miralles de Imperial y Pasqual del Pobil, María Ángeles Santos for permitting me to access Vives' files respectively preserved at the Archivo del Museo Arqueológico Nacional, Archivo General de la Universidad Complutense de Madrid, Biblioteca de la Real Academia de la Historia and Archivo del Instituto Valencia de Don Juan. Finally, a heartfelt thank you goes to Father Dominque Arnauld for his patience and for allowing me to consult and publish two letters from Father Delattre's correspondence; and to Jesús Salas Álvarez, who helped me at various stages during this work.

\section{REFERENCES}

Algerich Fernández, I. (2012). La fotografía en el Catálogo Monumental de España: procedimientos y autores. In A.

40. E.g. 'la dirección del Instituto Valencia de Don Juan se halla encomendada a D. Antonio Vives y al ingeniero Don Pedro de Artiñano, dos personas tan peritísimas que cuantos elogios de ellos se hiciesen serían pocos' ( $A B C$, Madrid, 19/04/1922)

41. He was Professor of Numismatics at the Universidad Central, head of the Instituto Valencia de Don Juan (1922-1925), collaborator of the MAN, and member of the Real Academia de la Historia, the German Archaeological Institute and of the Hispanic Society of America.
López-Yarto Elizalde (Ed). El Catálogo monumental de España (1900-1961): investigación, restauración y difusión (pp. 109-125). Madrid: Ministerio de Cultura y Deporte. Retreived from: https://sede.educacion.gob.es/publiventa/ detalle. action? $\operatorname{cod}=14089 \mathrm{C}$

Anuari de l'Institut d'Estudis Catalans (1909). Anuari de l'Institut d'Estudis Catalans MCMVIII. Retreived from: https:// publicacions.iec.cat/repository/pdf/00000100/00000043.pdf

Bermejo Tirado, J. \& Mañas Romero, I. (2012). La visión del arte clásico en el Catálogo Monumental de España. In A. López-Yarto Elizalde (Ed). El Catálogo monumental de España (1900-1961): investigación, restauración y difusión (pp. 205-223). Madrid: Ministerio de Cultura y Deporte. Retreived from: https://sede.educacion.gob.es/publiventa/ detalle. action? $\operatorname{cod}=14089 \mathrm{C}$

Bosch Gimpera, P. (1952). Problemas de la historia fenicia en el extremo occidente. Zephyrus, 3, 15-30.

Casado Rigalt, D. (2006). José Ramón Mélida y la Arqueología Española. Madrid: Real Academia de la Historia.

Castañeda, V. (1925). Fallecimiento del Catedrático Dr. Antonio Vives. ABC, 25th of May 1925, 15.

Cintas, P. (1946). Amulettes puniques. Tunis: Institut des hautes études.

Crespi, V. (1868). Catalogo illustrato della raccolta di antichità sarde possedute dal signor Raimondo Chessa. Cagliari: Tipografia Timon.

Delattre, A. L. (1897). Carthage. La nécropole punique de Douïmès, fouilles de 1893-1894. Cosmos, 1-31. Retreived from: https://www.tpsalomonreinach.mom.fr/document. php?id=3953

Delattre, A. L. (1899-1900). Catalogue du Musée Lavigerie, 3 vols. Tunisi: Impr. des Missionnaires d'Afrique.

Delattre, A. L. (1900). Lettre sur les fouilles de la nécropole punique voisine de la colline de Sainte Monique. Comptes rendus des séances de l'Académie des Inscriptions et Belles-Lettres, 44(1), 83-96. DOI: https://doi.org/10.3406/ crai.1900.16421

Díaz-Andreu, M., Mora, G. \& Cortadella, J. (Eds.). (2009). Diccionario Histórico de Arqueología de España (siglos $X V-X X)$. Madrid: Marcial Pons.

Dixon, P. (1940). The Iberians of Spain and their Relations with the Aegean World. Oxford: Oxford University Press.

Fernández Gómez, J. H. (1985). Necrópolis del Puig des Molins (Ibiza): nuevas perspectivas. Aula Orientalis, 3, 149-175.

Fernández Gómez, J. H. (2011). Antonio Vives Escudero. En Personatges de la nostra història, 4 (pp. 77-116). Eivissa: Associació d'Amics del Museu Arqueològic d'Eivissa i Formentera.

Fernández Gómez, J. H. (2016). La colección arqueológica ibicenca de Don Antonio Vives Escudero. Fites, 16, 18-28.

Fernández Gómez, J. H. (2018). Don Arturo Pérez-Cabrero y Tur y la Arqueología en Ibiza. Archivo de Prehistoria 
Levantina, XXXII, 307-344. Retreived from: http://mupreva. org/pub/1032/es

Fernández Gómez, J. H. (2020). El pleito entre Vives y Escudero y el Estado por las excavaciones en la necrópolis del Puig des Molins (Eivissa). Fites, 20, 17-31.

Ferrer Albelda, E. (1996). La España Cartaginesa. Claves historiográficas para la historia de España. Sevilla: Universidad de Sevilla.

Fumadó Ortega, I. (2009). Cartago: historia de la investigación. Madrid: Consejo Superior de Investigaciones Científicas.

García y Bellido, A. (1942). Fenicios y Cartagineses en Occidente. Madrid: Escuela de Estudios Hebraicos, C. Bermejo Imp.

Gracia Alonso, F. (2020). La concepción de la docencia sobre la cultura ibérica de Père Bosch Gimpera en 1917 a partir de los apuntes de clase de Lluís Pericot. Trabajos de Prehistoria, 77(2), 237-254. Retrieved from: https://doi.org/10.3989/ tp. 2020.12254

Guía Histórica y Descriptiva del Museo Arqueológico Nacional (1917). Madrid: Tip. de la Rev. de Arch., Bibl. y Museos.

Hernández, A. \& Marot, T. (2016). Antoni Vives Escudero i el col'leccionisme. In T. Marot (Coord.). Antoni Vives Escudero (1859-1925) col-leccionista, arqueòleg i acadèmic (pp. 7-12). Menorca: Museu de Menorca.

Heuzey, L. (1883). Les Figurines antiques de terre cuite $d u$ Musée du Louvre. Paris: Ve A. Morel et Cie.

Hübner, E. (1888). La Arqueología de España. Barcelona: Ramírez.

González Reyero, S. (2007). La Fotografia en la Arqueología Española. Madrid: Real Academia de la Historia - Universidad Autónoma de Madrid.

Lafuente, J. (1929). La necrópolis ibérica de El Molar (provincia de Alicante). Boletín de la Real Academia de Historia, $X C I V, 617-632$.

Maier, J. (1992). La necrópolis de «La Cruz del Negro» (Carmona, Sevilla): Excavaciones de 1900 a 1905. Cuadernos de Prehistoria y Arqueología de la Universidad Autónoma de Madrid, 19, 95-141. DOI: https://doi.org/10.15366/ cupauam1992.19.004

Martínez y Martínez, F. (1943). Antigüedades de Altea: Capnegret. Saitabi, 1(7-8), 22-26.

Mauro, C. M. \& Salas Álvarez, J. (2020). Antonio Vives Escudero e l'inizio del collezionismo di reperti fenicio-punici in Spagna. In C. Cecalupo (Ed.). Le storie degli oggetti. I reperti fenicio-punici nelle collezioni d'Europa (pp. 33-47). Supplementi alla Rivista di Studi Fenici. Roma: Consiglio Nazionale delle Ricerche.

Mederos Martín, A. (2001). Fenicios evanescentes. Nacimiento, muerte y redescubrimiento de los fenicios en la Península Ibérica. I. (1780-1935). Saguntum, 33, 37-48. Retrieved from: https://ojs.uv.es/index.php/saguntum/article/ view/1887
Mederos Martín, A. (2014). Antonio Vives y Escudero, coleccionista, arqueólogo, y primer Catedrático de Numismática de la Universidad de Madrid. In C. Ferrando \& B. Costa (Eds.). In Amicitia. Miscellània d'Estudis en homenatge a Jordi H. Fernández (pp. 417-431). Eivissa: Museu Arqueològic d'Eivissa i Formentera.

Mélida Alinari, J. R. \& Álvarez Ossorio, F. de P. (1896). Museo Arqueológico Nacional. Sección primera: sus aumentos desde la celebración de las Exposiciones Históricas. Boletin de Archivos, Bibliotecas y Museos, I(9), 177-187.

Mélida Alinari, J. R. (1898). Viaje á Grecia y Turquía. Revista de Archivos, Bibliotecas y Museos, II(6), 241-257.

Mélida Alinari, J. R. (1925). Don Antonio Vives. Revista de Archivos, Bibliotecas y Museos, XXIX(4-6), 237-239.

Numismatic Chronicles (1918). Review Work: Estudio de Arqueología Cartaginesa. La Necrópolis de Ibiza by Don Antonio Vives y Escudero. The Numismatic Chronicle, 18, 129-130.

Paris, P. (1899). L'âne de Silène. Ornement d'un biselliaum de bronce trouvé en Espagne. Bulletin hispanique, III(2), 113-134.

Pérez-Cabrero, A. (1911). Historia del Museo Arqueológico de Ibiza. Un Museo en Peligro. Barcelona: Tipografia L'Avenç.

Ponsich, M. (1968). Alfarerías de época fenicia y púnicomauritana en Kuass (Arcila, Marruecos). Saguntum, 4, 3-25.

Rada, J. de la. (1892). Catálogo de monedas arábigas españolas que se conservan en el Museo Arqueológico Nacional publicado siendo Director del mismo D. Juan de Dios de la Rada y Delgado. Madrid: Fortanet.

Renan, E. (1864). Mission de Phénicie. Paris: Imprimerie impériale.

Rodrigo del Blanco, J. (2018). La preparación de las Exposiciones Históricas. In J. Rodrigo del Blanco (Ed.). Las exposiciones históricas de 1892 (pp. 35-81). Madrid: Ministerio de Cultura y Deporte. Retreived from: http://www. man.es/dam/jcr:27e26bbb-9879-4696-8f02-d2e34ff01e9b/ eh3-preparacion.pdf

Rodríguez de Berlanga, M. (1902). La más antigua necrópolis de Cádiz y los primitivos civilizadores de la Hispania. Revista de Archivos, Bibliotecas y Museos, $3^{a}$ S., 5, 779-795.

Román y Calvet, J. (1906). Los nombres e importancia arqueológica de las islas Pythiusas. Barcelona: Tipografia L'Avenç.

Román Ferrer, C. (1913). Antigüedades ebusitanas. Barcelona: Tipografía La Académica, de Serra Hermanos y Russell.

Román Ferrer, C. (1922). Memoria de los resultados obtenidos en las excavaciones practicadas en 1921. Madrid: Imp. de la Rev. de Arch., Bibl. y Museos.

Román Ferrer, C. (1923). Memoria de los resultados obtenidos en las excavaciones practicadas en 1922. Madrid: Imp. de la Rev. de Arch., Bibl. y Museos. 
Román Ferrer, C. (1924). Memoria de los resultados obtenidos en las excavaciones practicadas en 1923. Madrid: Imp. de la Rev. de Arch., Bibl. y Museos.

Román Ferrer, C. (1926). Memoria de los resultados obtenidos en las excavaciones practicadas en 1924. Madrid: Imp. de la Rev. de Arch., Bibl. y Museos.

Román Ferrer, C. (1927). Memoria de los resultados obtenidos en las excavaciones practicadas en 1925. Madrid: Imp. de la Rev. de Arch., Bibl. y Museos.

Siret, L. (1908). Villaricos y Herrerías. Antigüedades púnicas, romanas, visigóticas y árabes. Madrid: Real Academia de la Historia.

Taramelli, A. (1914). La collezione di antichità sarde dell'ing. Leone Gouin. Bollettino d'arte del Ministero della Pubblica Istruzione, 8(7), 251-272.
Tarradell, M. \& Tarradell-Font, M. (1975). Eivissa Cartaginesa. Barcelona: Curial.

Vives, A. (1893). Monedas de las dinastías arábigo-españolas, 2 vols. Madrid: Fonumis.

Vives, A. (1909). Inventario de los monumentos artísticos de España. Provincia de Baleares. Manuscrito. CSIC (Biblioteca Tomás Navarro). Madrid. Retreived from: http://biblioteca. cchs.csic.es/digitalizacion tnt/index interior baleares.html

Vives, A. (1913). Estudio de clasificación de las monedas antiguas de Gades. Boletín de la Sociedad Española de Excursiones, 21, 289-321.

Vives, A. (1917). Estudio de Arqueología Cartaginesa. La necropoli de Ibiza. Madrid: Imp. de Blass y Cía.

Vives, A. (1923). Colección de antigüedades cartaginesas depositadas en el Museo Arqueológico Nacional. Inédito. MAN, Exp. 1923/60. 